\title{
Calcium, phosphorus and magnesium requirement
}

\author{
By D. H. Marshall, B. E. C. Nordin and R. Speed, MRC Mineral Metabolism \\ Unit, The General Infirmary, Great George Street, Leeds $L S_{\mathbf{I}}{ }_{3} E X$
}

The nutrient requirement of an adult can be defined in various ways, some of which are unfortunately not amenable to direct measurement. Thus if we define requirement as the amount required to preserve normal health we come up against the impossible task of measuring normal health. Similarly, if we define it as the amount required to preserve normal weight, we encounter the difficulty of defining normal weight. These difficulties can be avoided with mineral nutrients, which pass through the body unchanged, by defining the requirement as the amount needed to preserve mineral balance. It can hardly be disputed that prolonged negative mineral balance (be it of sodium, potassium, magnesium, phosphorus or calcium) must ultimately deplete the body stores and be detrimental to health.

This definition is adequate as far as it goes but is probably not quite sufficient. Adaptation to low intakes of $\mathrm{Mg}$ and $\mathrm{P}$ is achieved by lowering the plasma concentration and so lowering the urinary excretion. It would clearly be misleading to define requirement purely on the preservation of balance if this preservation of balance involved such a lowering of the plasma concentration of the nutrient concerned that it significantly impaired normal health. Thus there is abundant experimental evidence on animals and confirmatory data in man that hypophosphataemia can lead to osteomalacia (Lotz, Zisman \& Bartter, 1968). Our definition of mineral requirement, therefore, has to take into account the preservation of a normal, or at least a safe, plasma concentration of the nutrient concerned.

The purpose of the present communication is to look briefly at the $\mathrm{Mg}$ and $\mathrm{P}$ requirements of adults, which appear to be relatively low, and contrast them with the requirement for $\mathrm{Ca}$, which is relatively high. We suggest that there are at least three reasons for this difference between $\mathrm{Mg}$ and $\mathrm{P}$ on the one hand and $\mathrm{Ca}$ on the other. First, there are differences in the absorptive mech.anisms for the three elements. Secondly, there are differences in the plasma homoeostatic mechanisms. And thirdly, there are differences in the regulation of urinary excretion. In addition, there seem to be age and sex effects on $\mathrm{Ca}$ requirement but no comparable age and sex effects on $\mathrm{Mg}$ requirement.

\section{Methodology}

Our balances were performed by the standard procedure previously described (Bullamore, Nordin, Wilkinson \& Marshall, 1971; Gallagher \& Wilkinson, 1973). 
We administer a constant diet and a non-absorbable marker (polyethylene glycol) for 2 weeks and collect faeces and urine daily from days 8 to 14. The final balance is the mean of the daily balances in the second week.

\section{Magnesium requirement}

The (US) National Research Council (1974) recommends a Mg allowance of $300-500 \mathrm{mg} / \mathrm{d}$ for adults. Using the data from $94 \mathrm{I} \mathrm{Mg}$ balance experiments collected from the literature, Seelig (1964) claimed that after allowing for sweat losses the minimum $\mathrm{Mg}$ requirement was $6 \mathrm{mg} / \mathrm{kg}$ body-weight per d or about 400 $\mathrm{mg} / \mathrm{d}$, which would make the allowance even higher. In our opinion, both these estimates are too high.

Magnesium balances. We have performed $208 \mathrm{Mg}$ balances in miscellaneous subjects and found a simple linear relation between $\mathrm{Mg}$ intake and output with a slope of 0.83 and an intercept at theoretical zero intake of $37 \mathrm{mg}$ (Fig. I).

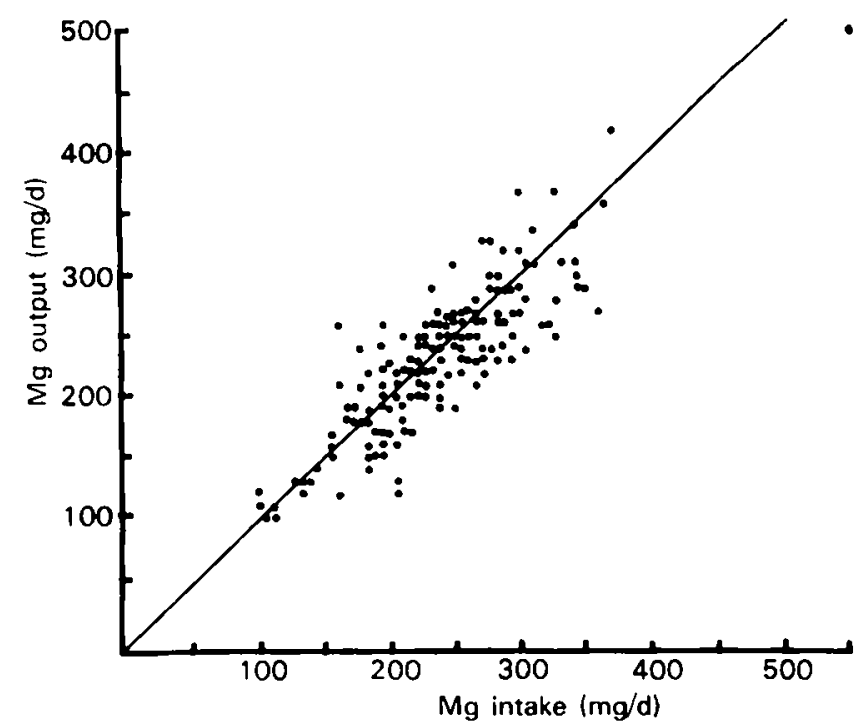

Fig. I. The relationship between magnesium output and $\mathrm{Mg}$ intake in 208 balances on miscellaneous subjects. The line of equality is indicated.

Regression of output $v$. intake yields a mean equilibrium value of $223 \mathrm{mg}$, which might be regarded as the mean requirement and is compatible with the recommended USA allowance of $300-350 \mathrm{mg} / \mathrm{d}$. However, inspection of the data shows that this calculation depends entirely on the preponderance of positive balances at high intakes; there is no corresponding preponderance of negative balances at low intakes, which would be expected if there were a genuine mean requirement of $223 \mathrm{mg} / \mathrm{d}$. In fact, the data suggest that negative $\mathrm{Mg}$ balance can be prevented at least down to intakes of $100 \mathrm{mg} / \mathrm{d}$, and that the $\mathrm{Mg}$ requirement must be below this value but cannot be defined from our data. This is entirely compatible with the findings of experiments which have had to use dietary $\mathbf{M g}$ 


\section{Vol. 35 Sex differences in response to nutritional variables $\quad{ }_{16}$}

levels of $10-20 \mathrm{mg}$ daily to produce $\mathrm{Mg}$ depletion (Fourman, I96r; Shils, 1969). We therefore turn to the consideration of plasma $\mathbf{M g}$ homoeostasis in an attempt to define $\mathbf{M g}$ requirement in terms of maintenance of plasma $\mathbf{M g}$.

Plasma magnesium. The normal range of plasma $\mathrm{Mg}$ in adults is $0.70-0.95$ $\mathrm{mmol} / \mathrm{l}$. The $\mathrm{Mg}$ throughput required to maintain the lower limit of this normal range can be estimated from the relation between plasma and urinary $\mathrm{Mg}$ in normal subjects (Nordin, 1976). This shows that when the plasma $\mathrm{Mg}$ is at the lower normal limit, the mean $\mathrm{Mg}$ excretion is about $8 \mu \mathrm{mol} / \mathrm{l}$ glomerular filtrate, or approximately $30 \mathrm{mg} / \mathrm{d}$ in a subject with a glomerular filtration rate of $100 \mathrm{ml} / \mathrm{min}$. This therefore represents an estimate of the absorbed $\mathrm{Mg}$ required to maintain a normal plasma level. Since the $\mathrm{Mg}$ absorption is about $35 \%$ of intake this points to a daily $\mathrm{Mg}$ intake of about $100 \mathrm{mg}$. The allowance should be somewhat higher.

Conclusion. It is therefore safe to say that normal subjects, eating normal diets containing $300-400 \mathrm{mg} \mathrm{Mg} / \mathrm{d}$, run no risk of $\mathrm{Mg}$ deficiency whether we define such deficiency as a negative $\mathrm{Mg}$ balance or a low plasma $\mathrm{Mg}$ concentration. This accords with clinical experience inasmuch as $\mathrm{Mg}$ deficiency states are never encountered in the absence of gastrointestinal or renal disease, or some highly artificial situation such as post-operative intravenous feeding.

\section{Phosphorus requirement}

The (US) National Research Council (I974) recommends a P allowance of 800 $\mathrm{mg} / \mathrm{d}$ for adults.

Our data suggest that the position with regard to $P$ balance is rather similar to that of $\mathrm{Mg}$. In our $646 \mathrm{P}$ balances on miscellaneous subjects, output is very closely related to intake, certainly down to a $P$ intake of $400 \mathrm{mg} / \mathrm{d}$ (Fig. 2). It is true that most of the balances are positive at high intakes, but there is no suggestion of the

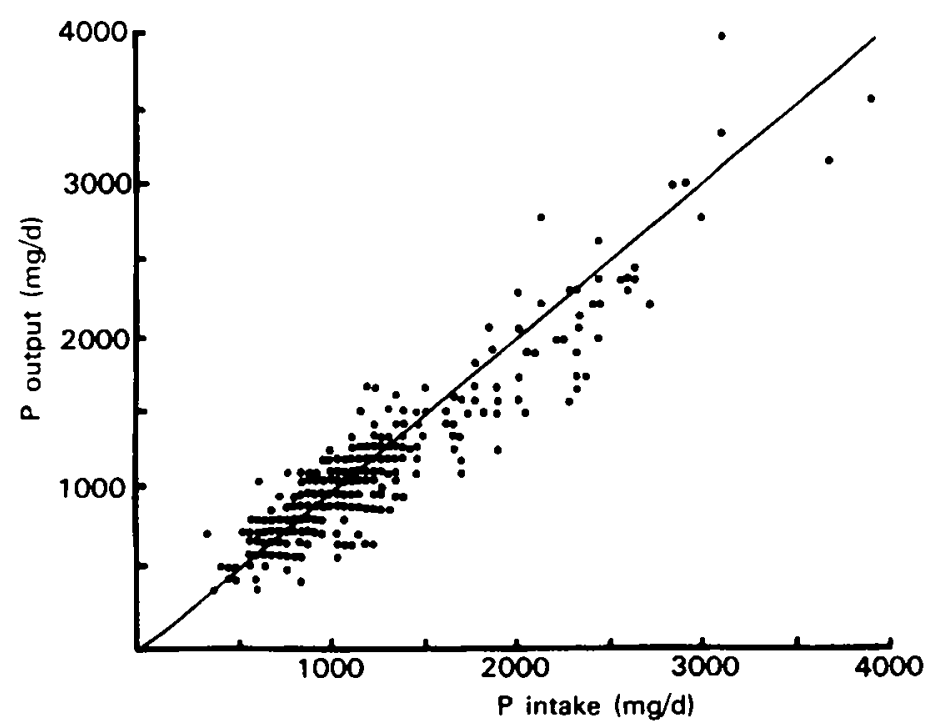

Fig. 2. The relationship between phosphorus output and $P$ intake in 646 balances on miscellaneous subjects. The line of equality is indicated. 
population moving into negative balance at the lower intakes. It does not therefore seem possible to define a $P$ requirement on these data. More balances at low intakes will be needed to define this value, but it would appear to be less than 400 $\mathrm{mg} / \mathrm{d}$. We shall therefore consider whether $P$ requirement can be defined in terms of plasma phosphate homoeostasis.

Plasma phosphate. The rate of phosphate flow through the plasma required to maintain a normal plasma phosphate concentration can be estimated from the normal relation between plasma and urinary phosphate (Robertson, 1976). This relationship is such that the lower normal limit of plasma phosphate concentration $(0.775 \mathrm{mmol} / \mathrm{l})$ is associated with a mean urine phosphate flow of about 0.058 $\mathrm{mmol} / \mathrm{l}$ glomerular filtrate, corresponding to about $8.4 \mathrm{mmol} / 24 \mathrm{~h}$ when the glomerular filtration rate is $100 \mathrm{ml} / \mathrm{min}$. The dietary $P$ required to produce this flow rate is about $400 \mathrm{mg} / \mathrm{d}$, since net absorption is $60 \%$ of intake. This value is also so far below the mean normal value for absorbed phosphate that there can be no danger of significant hypophosphataemia within the normal dietary range. Thus both on balance and plasma level criteria, the $\mathrm{P}$ requirement seems to be not more than $400 \mathrm{mg} / \mathrm{d}$. The allowance should presumably be higher, but whether it needs to be as high as $800 \mathrm{mg} / \mathrm{d}$ seems unlikely.

\section{Calcium requirement}

The situation with regard to $\mathrm{Ca}$ is rather different. We have collected and analysed 2 I2 $\mathrm{Ca}$ balances on eighty-four normal subjects published in the literature (see Appendix for references) and found that although $\mathrm{Ca}$ output is a function of $\mathrm{Ca}$ intake, the relationship between them differs from the corresponding $\mathrm{Mg}$ and $\mathrm{P}$ relationship (Fig. 3). Simple inspection shows that most

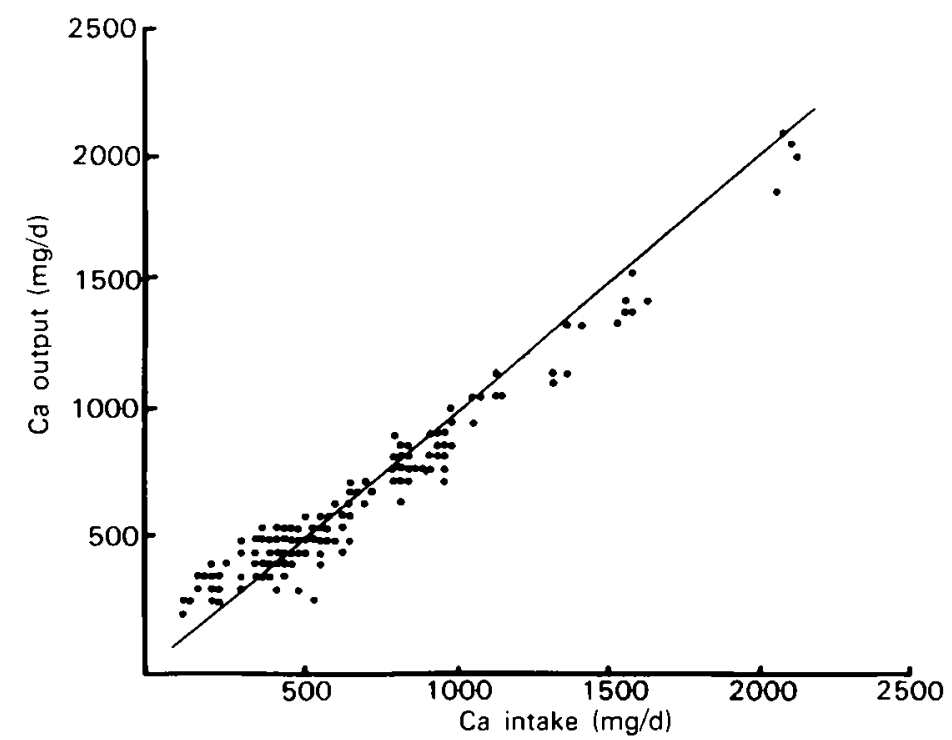

Fig. 3. The relationship between calcium output and $\mathrm{Ca}$ intake in $212 \mathrm{Ca}$ balances on eighty-four normal subjects published in the literature. The line of equality is indicated. 
balances are negative at intakes below $600 \mathrm{mg} / \mathrm{d}$ and positive at intakes above this level. This is a relatively high equilibrium value, or mean requirement, for which there are several explanations.

First, although net absorbed $\mathrm{Ca}$ is a function of dietary $\mathrm{Ca}$, it is negative at intakes below $190 \mathrm{mg} / \mathrm{d}$, due to a relatively high loss of $\mathrm{Ca}$ into the gastrointestinal tract via the digestive juices, only some of which is reabsorbed (Fig. 4). Thus there is a mean $\mathrm{Ca}$ requirement of $190 \mathrm{mg} / \mathrm{d}$ simply to avoid a net loss of $\mathrm{Ca}$ through the gastrointestinal tract.

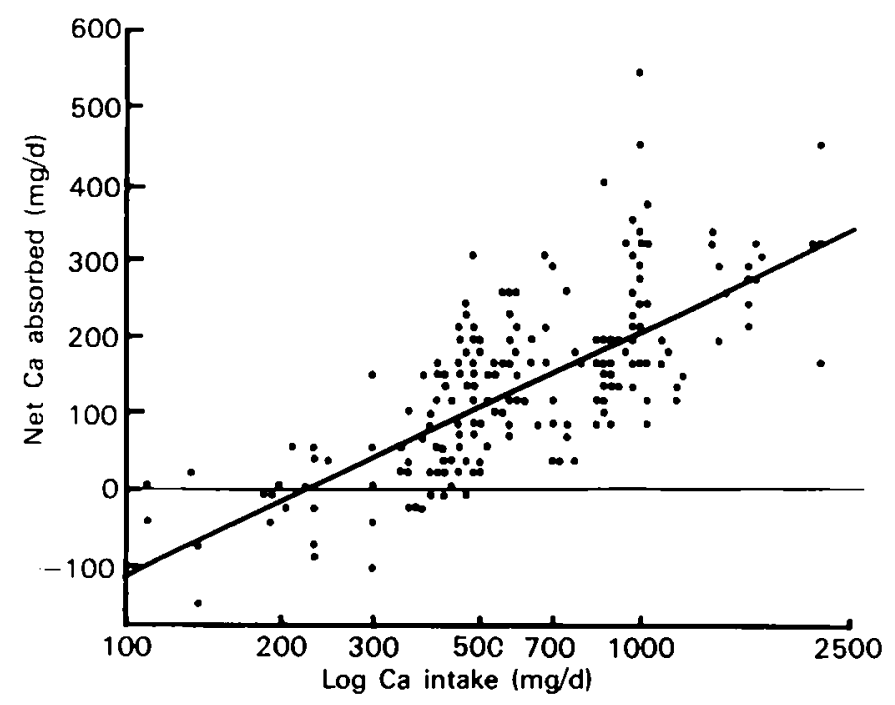

Fig. 4. The relationship between calcium absorbed and $\log \mathrm{Ca}$ intake in the $\mathrm{Ca}$ balances depicted in Fig. 3. The calculated regression line is indicated $(r 0.724 ; P<0.001)$.

Secondly, after the $\mathrm{Ca}$ has been absorbed, its excretion differs from that of $\mathrm{Mg}$ and $P$ with the result that an additional requirement arises from a relatively large obligatory loss of $\mathrm{Ca}$ in the urine. Whereas with $\mathrm{Mg}$ and $\mathrm{P}$, excretion is a linear function of dietary intake which passes virtually through the origin, i.e. urinary $P$ and $\mathrm{Mg}$ approach zero values in severe dietary deficiency, urinary $\mathrm{Ca}$ is not a simple linear function of dietary $\mathrm{Ca}$ and certainly does not approach zero at low $\mathrm{Ca}$ intakes (Fig. 5). The mean urinary $\mathrm{Ca}$ at theoretical zero $\mathrm{Ca}$ intake in normal subjects is $110 \mathrm{mg} / \mathrm{d}$, but the absorbed $\mathrm{Ca}$ does not reach the Ca excretion (so establishing $\mathrm{Ca}$ balance) until it amounts to about $\mathrm{r} 60 \mathrm{mg} / \mathrm{d}$ (Fig. 6). This amount is absorbed when the diet contains about $600 \mathrm{mg} \mathrm{Ca} / \mathrm{d}$, which is therefore one estimate of the mean $\mathrm{Ca}$ requirement.

The reason for this apparently inappropriate relation between absorbed and excreted $\mathrm{Ca}$ at low $\mathrm{Ca}$ intakes probably lies in the physiological system which governs plasma $\mathrm{Ca}$ homoeostasis. Unlike plasma $\mathrm{Mg}$ and phosphate, which are labile values and vary with response to dietary intake, the plasma $\mathrm{Ca}$ never falls below $2.25 \mathrm{mmol} / \mathrm{l}$ in normal subjects, even on very low-Ca diets, because of the 


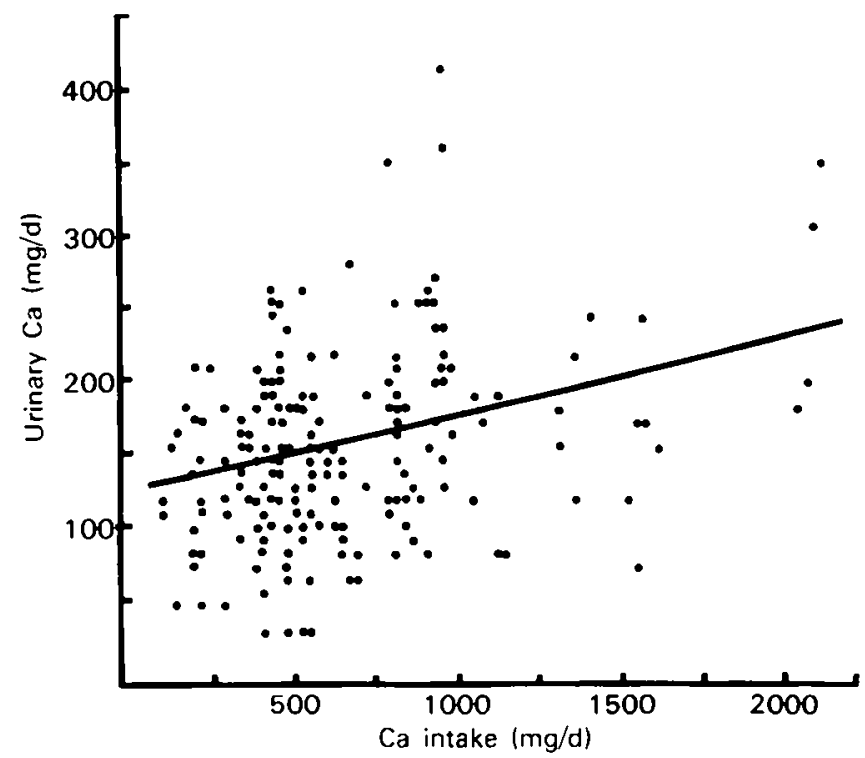

Fig. 5. The relationship beteen urinary calcium and $\mathrm{Ca}$ intake in the $\mathrm{Ca}$ balances depicted in

Fig. 3. The calculated regression line is indicated $(r 0.310 ; P<0 . \infty 1)$.

intervention of the parathyroid gland feedback mechanism. The secretion of parathyroid hormone maintains the plasma $\mathrm{Ca}$ at this minimum value by, in the first instance, increasing $\mathrm{Ca}$ absorption and tubular reabsorption of $\mathrm{Ca}$, and, if these mechanisms are insufficient, by increasing bone resorption (Peacock \& Nordin, 1973). In the final analysis, the organism will sacrifice the skeleton to maintain the plasma $\mathrm{Ca}$ concentration rather than preserve the skeleton intact and allow the plasma $\mathrm{Ca}$ concentration to fall.

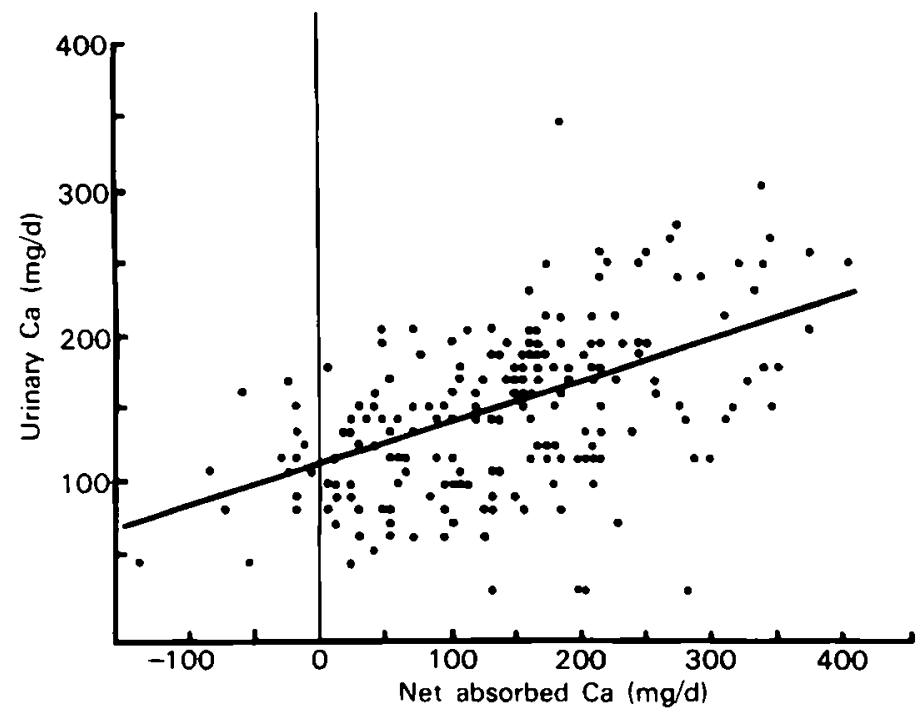

Fig. 6. The relationship between absorbed calcium and urinary $\mathrm{Ca}$ excretion in the $\mathrm{Ca}$ balances depicted in Fig. 3. The calculated regression line is indicated $(r 0.515 ; P<0.001)$. 
The mean urinary $\mathrm{Ca}$ when the plasma $\mathrm{Ca}$ is at the lower normal limit of 2.25 $\mathrm{mmol} / 1$ is about $0.025 \mathrm{mmol} / 1$ glomerular filtrate or about $150 \mathrm{mg}$ daily, as calculated from the simultaneous observation of plasma and urinary $\mathrm{Ca}$ before and during $\mathrm{Ca}$ infusion (Marshall, 1976). This value is eventually the same as the 160 $\mathrm{mg}$ absorbed $\mathrm{Ca}$ estimated to be required from the balance data.

Thus by both methods, the mean Ca requirement seems to be about $600 \mathrm{mg} / \mathrm{d}$, which is extremely close to the value of $9.3 \mathrm{mg} / \mathrm{kg}$ body-weight per $\mathrm{d}$ calculated by Mitchell \& Curzon (1939) from $139 \mathrm{Ca}$ balances which had appeared in the literature up to that date. However, the median requirement, which is similar to the mean value, would by definition protect only $50 \%$ of the population. The recommended allowance should perhaps be the intake which protects $95 \%$ of the population.

To calculate this from the $212 \mathrm{Ca}$ balances, we have assumed an error on each balance of up to $30 \mathrm{mg} / \mathrm{d}$ or $5 \%$ (whichever was the greater) and have assumed the individual to be in balance unless the stated negative $\mathrm{Ca}$ balance exceeded this amount. (The effect of this is of course to reduce the calculated requirement and recommended allowance.) We have then calculated the proportion of the 212 balances which are negative at different intake levels and plotted this against the $\log$ of the intake (Fig. 7). It will be seen that after our correction for possible error, $50 \%$ of the balances are negative at an intake of $500 \mathrm{mg} / \mathrm{d}$, which is the corrected mean requirement. To establish the amount required to preserve balance in $95 \%$ of the population, we have transformed the percentage in negative balance onto a logit scale, which then produces a linear relation between percentage in balance and $\log \mathrm{Ca}$ intake (Fig. 8). This shows that the intake required to protect $95 \%$ of the population is about $900 \mathrm{mg} / \mathrm{d}$. Moreover, the upper limit of Ca excretion at a

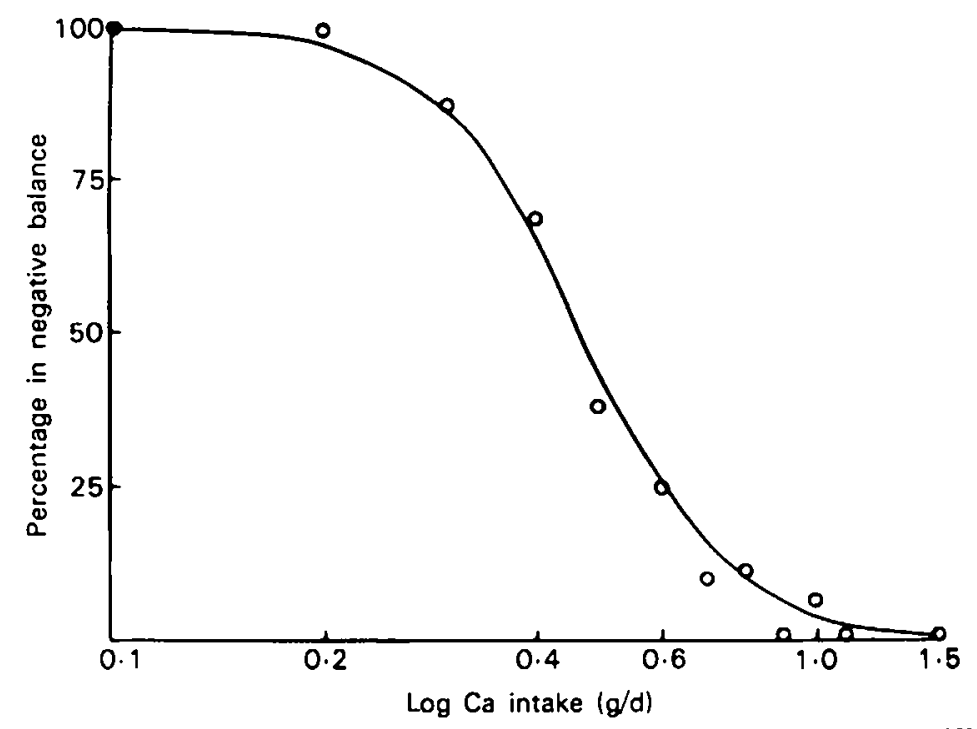

Fig. 7. The percentage of 212 normal calcium balances which are negative at different intake levels $v$. log $\mathrm{Ca}$ intake. (The balances have been corrected for an error of $30 \mathrm{mg} / \mathrm{d}$ or $5 \%, 88$ indicated above). 
plasma Ca level of $2.25 \mathrm{mmol} / \mathrm{l}$ is in fact about $0.038 \mathrm{mmol} / 1$ glomerular filtrate (Marshall, 1976), which represents $216 \mathrm{mg} \mathrm{Ca}$ absorbed/d, or an intake of about $900 \mathrm{mg} / \mathrm{d}$.

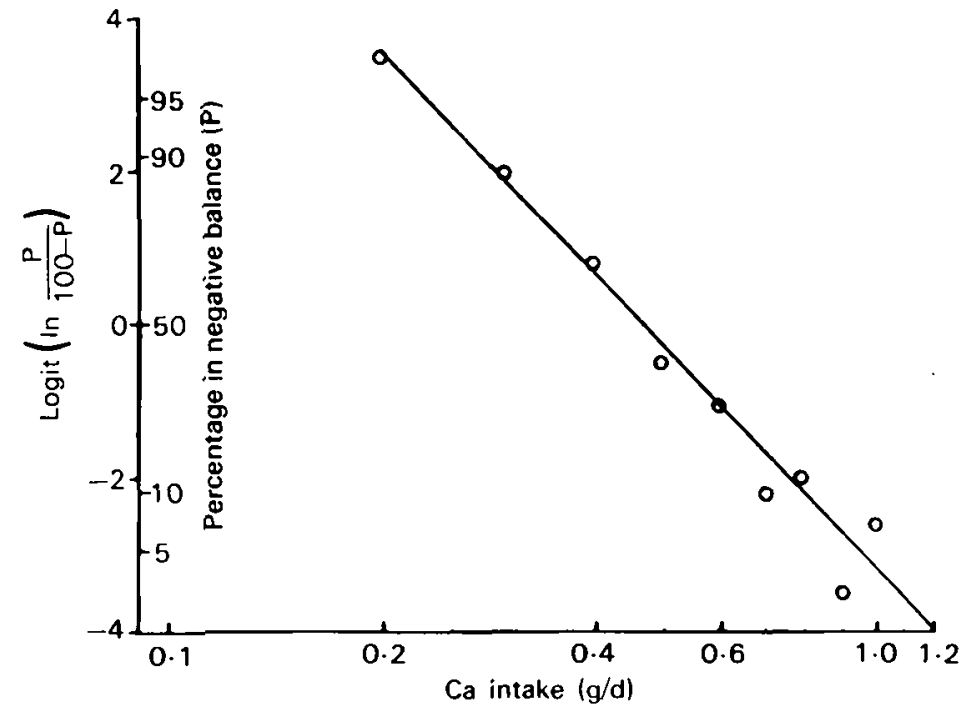

Fig. 8 The percentage of $2 \mathrm{I} 2$ normal calcium balances that are negative $(\mathrm{P})$ shown on a logit scale $\left(\ln \frac{\mathrm{P}}{100 . \mathrm{P}}\right)$ and related to $\log \mathrm{Ca}$ intake.

These considerations suggest that the recommended $\mathrm{Ca}$ allowance should be approximately $900 \mathrm{mg} / \mathrm{d}$ and not the $500 \mathrm{mg}$ recommended by the FAO/WHO expert group in 1962 (FAO/WHO, 1962) and subsequently accepted by the Department of Health and Social Security (1969). If these earlier recommendations had any scientific basis whatever (which seems rather doubtful) it was perhaps the mean $\mathrm{Ca}$ requirement, which is not of course the same as the recommended allowance.

\section{The effects of age and sex Males}

The best available data on the Ca requirement of men are still to be found in the work of Malm (1958) who, by means of prolonged $\mathrm{Ca}$ balances at various $\mathrm{Ca}$ intakes in twenty-six men, concluded that their mean requirement was $465 \mathrm{mg} / \mathrm{d}$ (CV 23.1). These men were aged 20-69 years and although the mean requirement was slightly higher in the older than the younger men $\left(485\right.$ v. $44^{\circ}$ $\mathrm{mg} / \mathrm{d}$ ) this difference was not significant. Thus the Ca requirement of $95 \%$ of fully adapted men would appear to fall within the range $210-720 \mathrm{mg} / \mathrm{d}$, and the allowance for such men should be $700-800 \mathrm{mg} / \mathrm{d}$.

\section{Females}

Young women. The best available set of data in young women are still the 275 $\mathrm{Ca}$ balances collected by Knapp (1943). When output is related to intake in these 
balances, the crossover point is about $600 \mathrm{mg} / \mathrm{d}$, i.e. most of the balances are negative below this value and positive above it. The data are in fact very similar to the 212 balances collected by us in normal subjects.

Post-menopausal women. We know of no substantial series of balance studies on post-menopausal women, the group which is of course of particular interest because of the bone loss which starts at this time of life (Nordin, 1971). We have, therefore, used our own balance data and have analysed all the post-menopausal balances available to date. This series comprises sixty-one post-menopausal women with varying degrees of 'spinal osteoporosis'. There is no obvious difference between those with and those without vertebral fractures and the data have therefore been pooled.

The relationship between $\mathrm{Ca}$ output and intake in these sixty-one balances is shown in Fig. 9. It will be seen that most of these subjects are in negative $\mathrm{Ca}$ balance at all $\mathrm{Ca}$ intakes. In other words, their $\mathrm{Ca}$ requirement appears to be increased, though it is impossible to define it from these data because there is no crossover point.

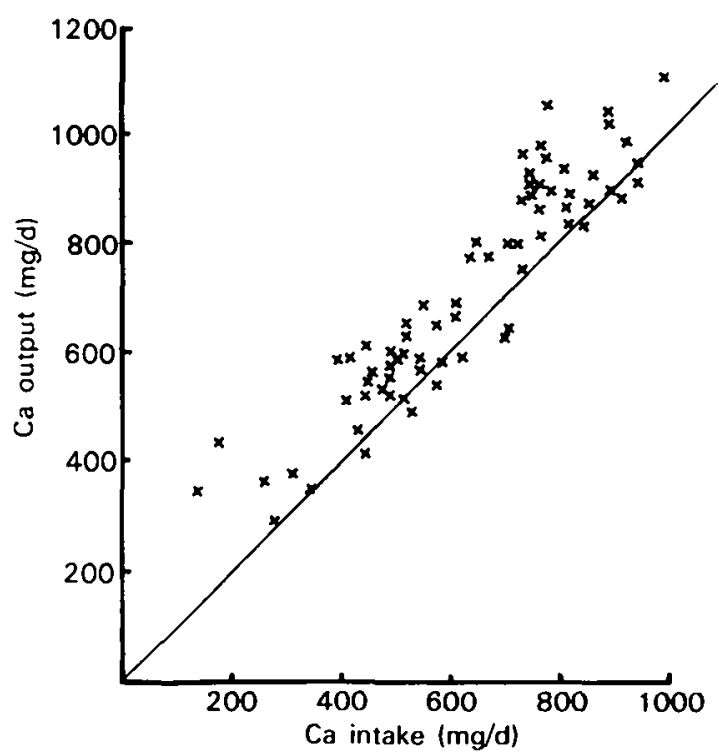

Fig. 9. The relationship between calcium output and $\mathrm{Ca}$ intake in sixty-one $\mathrm{Ca}$ balances on post-menopausal women. The line of equality is indicated.

It is difficult to escape the conclusion that the negative Ca balance of about $50-70 \mathrm{mg} / \mathrm{d}$ in our post-menopausal women reflects the loss of bone which is occurring at this time of life at a rate of about $\mathrm{i} \%$ per annum, representing a $\mathrm{Ca}$ loss of about $30-35 \mathrm{mg} / \mathrm{d}$. Closer agreement than this between these two values could hardly be expected with existing techniques.

The reason for this increased $\mathrm{Ca}$ requirement, if such it may be called, is a reduced $\mathrm{Ca}$ absorption, sometimes an impaired renal conservation of $\mathrm{Ca}$ and sometimes both, the ultimate cause probably being oestrogen deficiency. As we 
have reported elsewhere (Horsman \& Nordin, 1976) Ca balance tends to be more negative in post-menopausal women with severe oestrogen deficiency than in those who are moderately well oestrogenized, and we have also noted that women with severe oestrogen deficiency tend to lose bone faster than other post-menopausal women. Moreover, the negative $\mathrm{Ca}$ balance can always be corrected with oestrogen therapy (Gallagher \& Nordin, 1975).

\section{Conclusions and summary}

Our data suggest that there is a fundamental difference between $\mathrm{Ca}$ as a nutrient on the one hand and $\mathrm{Mg}$ and $\mathrm{P}$ on the other. Owing to the nature of the $\mathrm{Ca}$ absorptive mechanism, the mechanism of plasma $\mathrm{Ca}$ homoeostasis and the control of $\mathrm{Ca}$ excretion, $\mathrm{Ca}$ requirement is perceptibly higher than that of other comparable nutrients. The recommended dietary allowance of $\mathrm{Ca}$ must rest on this fundamental concept. Approximately $800 \mathrm{mg} \mathrm{Ca} / \mathrm{d}$ is needed to meet the $\mathrm{Ca}$ requirement even of men and young women. The $\mathrm{Ca}$ requirement of postmenopausal women is probably substantially higher, but the correct approach to this group is likely to be oestrogen-replacement therapy rather than $\mathrm{Ca}$ supplementation. However, oestrogen-replacement therapy is contraindicated in a significant number of women owing to ischaemic heart disease, a past history of thromboembolism and possibly hypertension. There are also some women who do not wish to take hormones after the menopause. It is possible therefore that ultimately a higher $\mathrm{Ca}$ allowance should be recommended for this age-group, but present knowledge does not enable one to define it with any degree of certainty.

\section{APPENDIX}

The 212 normal $\mathrm{Ca}$ balances used in this paper have been compiled from the following references. Consecutive balance periods at the same intake have been combined to produce single balance values.

Bogdonoff, M. D., Shock, N. W. \& Nichols, M. P. (1953). Y. Geront. 8, 272.

Clarkson, E. M., Durrant, C., Phillips, M. E., Cower, P. E., Jewkes, R. F. \& de Wardener, H. E. (1970). Clin. Sci. 39, 693.

Johnston, F. A., McMillan, T. J. \& Falconner, G. D. (1952). F. Am. diet. Ass. $28,933$.

Malm, O. J. (1958). Calcium Requirement and Adaptation in Adult Man. Oslo: Oslo University Press.

Malm, O. J., Nicolaysen, R. \& Skjelkvale, L. (1955). Ciba Fdn Collog. i, Iog.

Owen, E. C., Irving, J. T. \& Lyall, A. (1940). Acta med. scand. 103, 235.

Steggerda, F. R. \& Mitchell, H. H. (1939). J. Nutr. 17, 253.

Steggerda, F. R. \& Mitchell, H. H. (194I). J. Nutr. 2 I, 577.

Steggerda, F. R. \& Mitchell, H. H. (1946). Ұ. Nutr. 31, 407.

Steggerda, F. R. \& Mitchell, H. H. (1951). J. Nutr. 45, 201.

\section{REFERENCES}

Bullamore, J. R., Nordin, B. E. C., Wilkinson, R. \& Marghall, D. H. (1971). Dynamic Studies with Radioisotopes in Medicine. Vienna: International Atomic Energy Agency.

Department of Health and Social Security (1969). Recommended Intakes of Nutrients for the United Kingdom. London: H.M. Stationery Office. 


\section{Vol. 35 Sex differences in response to nutritional variables}

FAO/WHO (1962). Tech. Rep. Ser. Wld Hlth Org. no. 230 (also issued as F.A.O. Nutr. Mtg Rep. Ser. no. 30).

Fourman, P. (196I). Scient. Basis Med. a. Rev. p. 270.

Gallagher, J. C. \& Nordin, B. E. C. (1975). In Frontiers of Hormone Research, vol. 3, Estrogens in the Post-Menopause, p. I50. [P. A. van Keep and C. Lauritzen, editors]. Basle: S. Karger.

Gallagher, J. C. \& Wilkinson, R. (1973). Clin. Sci. 45, 785.

Horsman, A. \& Nordin, B. E. C. (1976). Clin. Endocr. 5, Suppl. (In the Press).

Knapp, E. (1943). Studies in the urinary excretion of calcium. PhD Thesis, University of Iowa, USA.

Lotz, M., Zisman, E. \& Bartter, F. C. (1968). New Engl. J. Med. 278, 409.

Malm, O. J. (1958). Calcium Requirement and Adaptation in Adult Man. Oslo: Oslo University Press.

Marshall, D. H. (1976). In Calcium, Phosphate and Magnesium Metabolism, [B. E. C. Nordin, editor]. Edinburgh and London: Churchill Livingstone.

Mitchell, H. H. \& Curzon, E. G. (1939). Dietary Requirement of Calcium and its Significance. Paris: Hermann.

National Research Council (1974). Recommended Dietary Allowances, 8th ed. Washington, DC: National Academy of Sciences.

Nordin, B. E. C. (1971). Br. med. F. i, 57 r.

Nordin, B. E. C. (editor) (1976). In Calcium, Phosphate and Magnesium Metabolism, Edinburgh and London: Churchill Livingstone.

Peacock, M. \& Nordin, B. E. C. (1973). In Hard Tissue Growth, Repair and Remineralixation. Ciba Foundation Symposium no. 11, p. 409. [K. Elliott and D. W. Fitzsimons, editors]. Amsterdam: Associated Scientific Publishers.

Robertson, W. G. (1976). In Calcium, Phosphate and Magnesium Metabolism, [B. E. C. Nordin, editor]. Edinburgh and London: Churchill Livingstone.

Seelig, M. S. (1964). Am. F. clin. Nutr. 14, 342.

Shils, M. E. (1969). Medicine, Baltimore 48,61. 